\title{
AHP for Developing Land Valuation Model in Infrastructure Development
}

\begin{abstract}
Investment in infrastructure development for public purpose is very important for the development of any country. This investment often needs a huge quantity of land. Inadequacy of compensation amount i.e low valuation is one of the main causes for opposition and delays by affected land owners in land acquisition. GIS technology is not applied in land valuation for land acquisition in infrastructure development. Therefore, GIS with Analytic Hierarchy Process is an effective tool for dealing with complex decision by setting priorities and makes the best decision. In this context, the main objective of this study is to develop the land valuation model by using GIS and AHP for infrastructure development. The quantitative and qualitative research methodologies are adopted for this study. The pairwise comparisons of different criteria by its importance carried out from the response of different stakeholders and calculation of Eigenvector in Fast Track Road Project, Chattiwan VDC. The weightage overlay in GIS is carried out with road class, built up class, slope class, forest class, soil type class and river class by using weighted overlay tool. The joined weighted Parcel shapefile is added with fields, Government value, Market value, Raster Weight and Model Price. Then, the joined weighted parcel shapefile is visualized based on Model Price. The land value is determined with spatial analysis and Analytical Hierarchy Process. A numerical weight or priority is derived for each element of the hierarchy. The decision makers systematically evaluates its various elements by comparing them to each other two at a time.
\end{abstract}

Keywords: AHP, Land Valuation, Infrastructure

\section{Introduction}

Infrastructure development is one of the key indicators for development of any country. Investment in infrastructure development for public purpose is very important for the development of any country. This investment often needs a huge quantity of land. Inadequacy of compensation amount i.e low valuation is one of the main causes for opposition and delays by affected land owners in land acquisition (ORF, 2010). Not only this, most of infrastructure development projects terminated in the operation phase due to struggles caused by compulsory acquisition of land with low market value, such as, new airport project for Mexico city in 2002 (Cernea, 2003: ORF, 2010). GIS technology is not 
applied in land valuation for land acquisition in infrastructure development. Therefore, land valuation and management process is always controversial for infrastructure development. Therefore, GIS with Analytic Hierarchy Process is an effective tool for dealing with complex decision by setting priorities and makes the best decision. According to Saaty (2008), it is a theory of measurement through pairwise comparisons and depends on the judgments of experts to find out priority. Pair wise comparisons are based on forming judgments between two particular criterions rather than attempting to prioritize an entire list of criterions. Saaty (2008) has shown that weighting activities in multi-criteria decisionmaking can be effectively dealt using hierarchical structure and pairwise comparisons.

\section{Objective}

In this context, the main objective of this study is to develop the land valuation model by using GIS and AHP for infrastructure development

\section{Research Methodology}

The quantitative and qualitative research methodologies are adopted for this study. The quantitative data were collected from household survey and qualitative data are collected from key informants interview, focus group discussion and participant observation. The respondents for primary data collection were 105 representing affected families, Fast Track officials, land administration professionals, civil society member and local leaders as shown in Table 1

Table 1: Respondents for primary data collection

\begin{tabular}{|l|l|l|l|l|}
\hline Respondents & $\begin{array}{l}\text { Household } \\
\text { survey }\end{array}$ & $\begin{array}{l}\text { Department of } \\
\text { Road/Fast } \\
\text { Track official, } \\
\text { (Project } \\
\text { Director and } \\
\text { Engineers) }\end{array}$ & $\begin{array}{l}\text { Land } \\
\text { Administration } \\
\text { professional/ } \\
\text { decision maker }\end{array}$ & $\begin{array}{l}\text { VDC } \\
\text { representatives/Civil } \\
\text { society }\end{array}$ \\
\hline Numbers & 94 & 3 & 5 & 3 \\
\hline
\end{tabular}

The location map of case study area has been shown in Figure 1 


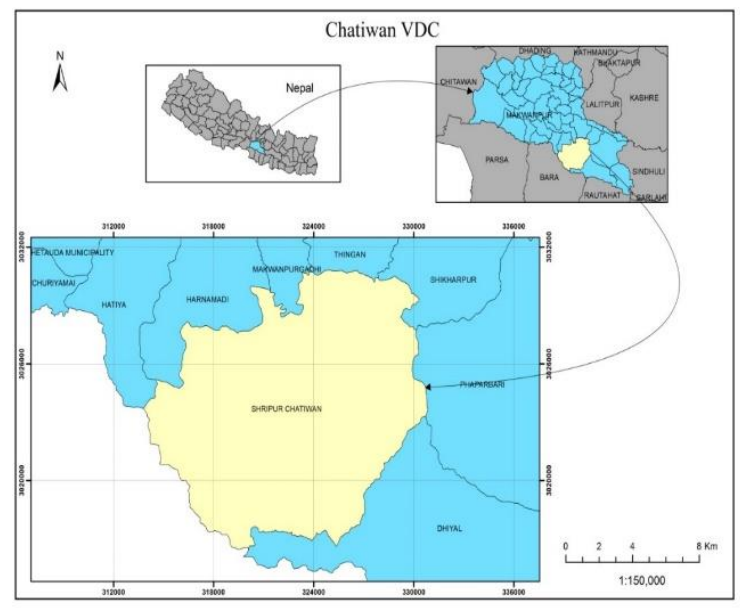

Figure 1: Location Map of Study area

\section{Data Analysis and Results}

The AHP is working with the matrix comparing each criterion to each other. The pairwise comparisons of different criteria by its importance carried out from the response of different stakeholders and calculation of Eigen vector in Fast Track Road Project, Chattiwan VDC are mentioned in Table 2 and Table 3 respectively

Table 2: Generalization of level of importance

\begin{tabular}{|l|r|l|}
\hline Criteria & Percentage & Level of importance \\
\hline Road & $100 \%$ & Very high important \\
\hline Built up & $72.38 \%$ & High important \\
\hline Slope & $66.67 \%$ & Very high important \\
\hline Natural environments (River \& forest) & $49.52 \%$ & Medium important \\
\hline Soil type & $42.71 \%$ & Medium important \\
\hline Social environments & $97.14 \%$ & Notimportant \\
\hline
\end{tabular}

Table3: Calculating Eigen vector

\begin{tabular}{|l|l|l|l|l|l|l|l|}
\hline $\begin{array}{l}\text { Land } \\
\text { valuation } \\
\text { criteria }\end{array}$ & Road & Slope & $\begin{array}{l}\text { Built } \\
\text { up }\end{array}$ & $\begin{array}{l}\text { Natural } \\
\text { environments }\end{array}$ & $\begin{array}{l}\text { Soil } \\
\text { type }\end{array}$ & $\begin{array}{l}\text { 5th } \\
\text { root of } \\
\text { product }\end{array}$ & $\begin{array}{l}\text { Eigen } \\
\text { vector }\end{array}$ \\
\hline Road & 1 & 1 & 3 & 5 & 5 & 2.371 & 0.360 \\
\hline Slope & 1 & 1 & 3 & 5 & 5 & 2.371 & 0.360 \\
\hline Built up & 0.333 & 0.333 & 1 & 3 & 3 & 0.998 & 0.160 \\
\hline
\end{tabular}




\begin{tabular}{|l|l|l|l|l|l|l|l|}
\hline $\begin{array}{l}\text { Natural } \\
\text { environments }\end{array}$ & 0.2 & 0.2 & 0.333 & 1 & 1 & 0.419 & 0.060 \\
\hline Soil type & 0.2 & 0.2 & 0.333 & 1 & 1 & 0.419 & 0.060 \\
\hline SUM & $\mathbf{2 . 7 3 3}$ & $\mathbf{2 . 7 3 3}$ & $\mathbf{7 . 6 6 6}$ & $\mathbf{1 5}$ & $\mathbf{1 5}$ & $\mathbf{6 . 5 7 8}$ & 1.000 \\
\hline SUM*PV & $\mathbf{0 . 9 8 3}$ & $\mathbf{0 . 9 8 3}$ & $\mathbf{0 . 8 3 0}$ & $\mathbf{1 . 1 5 7}$ & $\mathbf{1 . 1 5 7}$ & $\mathbf{5 . 1 1 0}$ & \\
\hline
\end{tabular}

The weightage overlay in GIS is carried out with road class, built up class, slope class, forest class, soil type class and river class by using weighted overlay tool. The weighted polygon is intersected with the parcel polygon with intersect tool. Finally, the joined weighted parcel shapefile is obtained. The joined weighted Parcel shapefile is added with fields, Government value (GV), Market value (MV), Raster Weight and Model Price. Then, the joined weighted parcel shapefile is visualized based on Model Price. Simlarly, the mathematical model for land valuation is:

$\mathrm{Vi}=\mathrm{R}^{*} \mathrm{AREAi}{ }^{*} \sum \mathrm{Wi}$

Value $=\sum \mathrm{Vi}$

Where, AREAi $=$ Area of each parcel, $\mathrm{WI}=$ Factor weight calculated from weighted overlay, $\mathrm{i}=1$ to $\mathrm{n}$, Number of each parcel, $\mathrm{R}=\left(0.6^{*}\right.$ Market rate $+0.4^{*}$ Government rate) and Value $=$ Total land value of each parcel

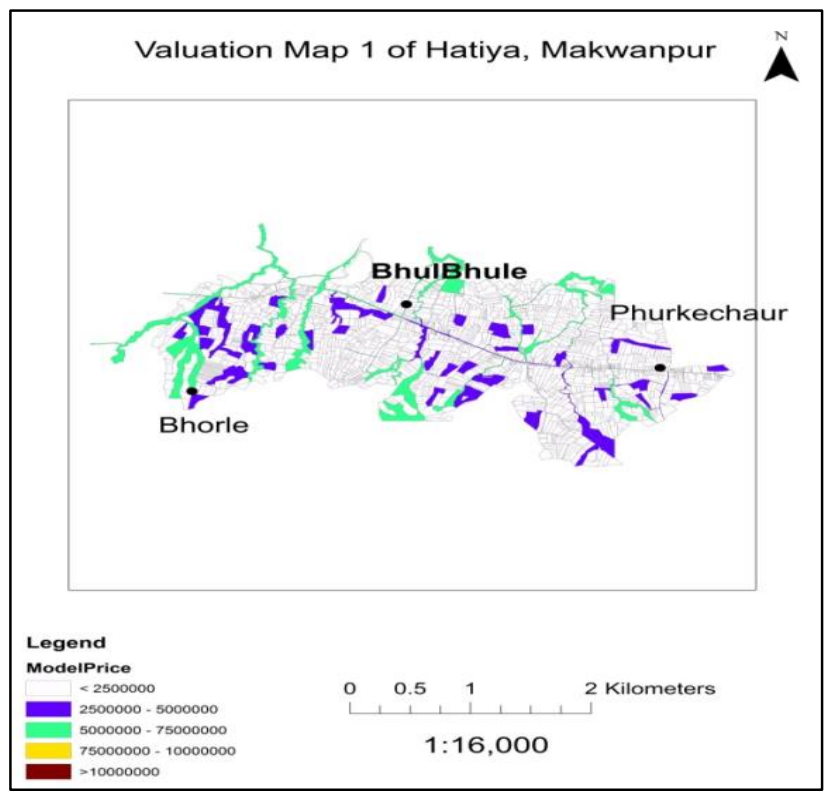

Figure 2: Valuation Map of Hatiya, Makawanpur

\section{Limitations}


The study has used criteria such as road, built up, slope, forest, soil type and river. Further study can be carried out including the other criteria for land valuation in land acquisition for infrastructure development.

\section{Conclusion}

The AHP is applied for land valuation in infrastructure development. The land valuation model for infrastructure development has been developed considering various criteria. The land value is determined with spatial analysis and Analytical Hierarchy Process (AHP). A numerical weight or priority is derived for each element of the hierarchy. The decision makers systematically evaluates its various elements by comparing them to each other two at a time. Land value modeling is carried out to determine the value of each parcel by using dependent variable, which is a land market price and independent variable which is parcel quality level. Independent variable is a synthesis of weight value of each criterion that influence parcel quality level.

\section{Key References}

Cernea, M. (2003). For a new economics of resettlement: A sociological critique of the compensation principle. International Journal of Social Science, 55 (175), 37-45.

ORF.(2010).Mega Project Development: Issues in Land Acquisition. Event Reports, New Delhi,Retrieved from https://www.orfonline.org/research/mega-projectdevelopment-issues-in-land-acquisition/

Saaty, T. L. (2008). Decision making with the analytic hierarchy process. International Journal of Services Sciences, 1 . Retrieved from http://www. rafikulislam.com/uploads/resourses/197245512559a37aadea6d.pdf. 